\title{
Upaya Meningkatkan Hasil Belajar Matematika Materi Pecahan Senilai Melalui Model Realistic Mathematics Education Siswa Kelas IV SDN 44 Bengkulu Tengah
}

Sunyiati

Guru SDN 44 Bengkulu Tengah

sunyitriantoro@gmail.com

\begin{abstract}
This research aims to improve activities and results of learning mathematics using the Realistic Mathematics Education model for grade IV students of SDN 44 Bengkulu Tengah. This type of research is a classroom action research conducted in two cycles. Research subjects were grade IV students of SDN 44 Bengkulu Tengah. Data collection instrument used teacher activity observation sheet, student activity and learning results tests. Data analysis technique using qualitative techniques to analyze data from observations and quantitative techniques to analyze the level of success of learning result. The results showed: 1) teacher activity in the first cycle obtained an average of 3.20 and in the second cycle an average of $3.70,2)$ student activity in the first cycle obtained an average of 3.30 and in the second cycle an average of $3.60,3)$ Learning result in the first cycle obtained an average of 68.75 with learning completeness $62.5 \%$, increased in the second cycle an average value of 80 with $87.5 \%$ learning completeness. The conclusion of this research that use the Realistic Mathematics Education model can improve the activity and learning result of class IV students of SDN 44 Bengkulu Tengah
\end{abstract}

Keyword: Realistic Mathematics Education, activity, learning result, mathematics

\section{Pendahuluan}

Matematika merupakan salah satu pelajaran yang wajib diajarkan di sekolah dasar dan memiliki peranan penting untuk membantu memecahkan masalah dalam kehidupan sehari-hari. Menurut Hadi (2017) mengemukakan bahawa pengajaran matematika di sekolah dasar bertujuan untuk menekankan pada penalaran logis, rasional dan kritis serta memberikan keterampilan untuk menggunakan penalaran matematika untuk memecahkan masalah dalam kehidupan sehari-hari.

Tujuan pembelajaran matematika di Sekolah Dasar diantaranya, siswa dapat memahami konsep matematika dan keterkaitan antar konsep serta mengaplikasikan konsep atau algoritma secara luwes, akurat, efisiensi dan tepat dalam pemecahan masalah (Depdiknas, 2006). Untuk mencapai tujuan tersebut sebaiknya dalam proses pembelajaran matematika disesuaikan dengan taraf perkembangan siswa Sekolah Dasar yang masih berada pada tahap operasional konkrit. Hal ini senada dengan pendapat Bruner (Muhsetyo, 2007) mengemukakan bahwa dalam pembelajaran matematika di sekolah dasar melalui tiga tahap, yaitu: 1) enaectiv yaitu memanipulasi objek secara langsung, 2) iconic yaitu memanipulasi objek tidak langsung atau melalui gambar dan 3) symbolic yaitu memanipulasi simbol-simbol matematika yang bersifat abstrak. 
Pembelajaran matematika di sekolah dasar dapat berhasil dengan baik, jika dalam belajar dibantu dengan benda-benda konkrit yang ada di lingkungan sekitar. Siswa diberi kesempatan memanipulasi benda-benda konkretatau alat peraga yang dirancang dan bisa dikotak-katik oleh siswa dalam menemukan konsep (Hawa, 2008). Menurut Trianto (2009) guru dapat menciptakan suatu kondisi belajar yang memadahi agar siswa mampu menemukan pengalaman-pengalaman nyata dan terlibat langsung dengan lingkungan. Dalam pembelajaran matematika menurut Heruman (2007) melalui tiga tahap, yaitu: 1) penanaman konsep dasar, ini merupakan jembatan yang menghubungkan kemampuan kognitif konkrit menuju ke abstrak, 2) pemahaman konsep,bertujuan agar siswa lebih memahami konsep matematika dan 3) pembinaan keterampilan bertujuan agar siswa lebih terampil menggunakan berbagai konsep matematika untuk memecahkan permasalahan sehari-hari.

Berdasarkan pengalaman peneliti sebagai guru dalam pembelajaran matematika di Kelas IV SDN 44 Bengkulu Tengah, ditemukan permasalahan sebagai berikut: 1) Penyajian materi pelajaran berorientasi pada buku paket yaitu, memberikan contoh soal, menjelaskan cara mengerjakan dan memberi soal latihan, 2) siswa tidak pernah dilatih menemukan konsep matematika, 3) dalam mengajarkan materi matimatika jarang menggunakanalat peraga benda-benda konkrit yang ada di lingkungan sekitar, 4) Nilai rata-rata rendah $(5,64)$ di bawah KKM mata pelajaran matematika $(70,0)$.

Menindaklanjuti permasalahan tersebut peneliti berkolaborasi dengan kepala sekolah dan teman sejawat untuk mencari solusi pemecahan masalah. Hasil diskusi disepakati untuk mengatasi permasalahan pembelajaran matematika digunakan model pembelajaran inovatif yang dapat mengaktifkan siswayaitu menggunakan model Realictic Mathematics Education (RME). Menurut Freudental dalam Shoimin (2014) mengemukakan bahwa dalam belajar matematika dikaitkan dengan realitas kehidupan sehari-hari dan matematika merupakan aktivitas manusia. Hal ini menekankan bahwa matematika sebagai aktivitas manusia yang relevan dengan situasi sehari-hari dan memberi kesempatan mengemukakan ide dan konsep matematika.

Penerapan model RME dalam pembelajaran matematika diharapkan dapat mengubah pembelajaran yang pasif menjadi aktif. Siswa dimotivasi terlibat secara aktif dan kreatif dalam menemukan konsep-konsep matematika. Melalui pembelajaran menggunakan RME diharapkan dapat meningkatkan aktivitas dan hasil belajar. Didukung penelitian Susilowati (2018), hasil penelitian menunjukkan bahwa penerapan RME pada pembelajaran matematika dapat meningkatkan hasil belajar dengan kategori tinggi dan aktivitas belajarnya kategori aktif. Selanjutnya Maulana (Isrok'atun, 2018) mengemukakan salah satu karakteristik RME yaitu proses pembelajaran matematika dilakukan secara interaktif, artinya terdapat interaksi di antara siswa dengan guru, siswa dengan siswa, siswa dengan lingkungan sekitar dalam bentuk mengkomunikasikan proses pemecahan masalah.Hasil penelitian Shandy (2016) menunjukkan bahwa dengan menggunakan model RME dapat meningkatkan hasil belajar siswa. Hasil penelitian menunjukkan pada siklus I diperoleh nilai rata-rata 70,6 dengan ketuntasan belajar 62\% dan meningkat pada siklus ke II diperoleh nilai rata-rata 88 dengan ketuntasan belajar $87 \%$.

Pembelajaran menggunakan model RME menggunakan langkah-langkah sebagai berikut: 1) Memahami masalah kontekstual, pada tahap ini guru memberikan soal atau masalah yang berkaitan dengan pecahan senilai dan siswa diminta untuk memahami masalah, 2) Menyelesaikan masalah kontekstual, pada tahap ini siswa diberi kesempatan menyelesaikan masalah yang diberikan di LKPD, 3) 
Membandingkan dan mendiskusikan jawaban, pada tahap ini siswa diminta mendiskusikan jawaban bersama kelompok setelah itu hasil diskusi dibandingkan dengan kelompok lain, 4) Menarik kesimpulan, pada tahap ini guru mengarahkan menarik kesimpulan (Shoimin, 2014). Penerapan model RME lebih menekankan pada proses pembelajaran. Proses pembelajaran matematka menjadi kunci utama dalam memahami suatu konsep, mengaplikasikan keterkaitan konsep untuk pemecahan masalah dalam kehidupan sehari-hari, sehingga pembelajaran lebih bermakna (Isrok'atun, 2012). Adapun tujuan Penelitian Tindakan Kelas ini adalah untuk meningkatkan aktivitas dan hasil belajar matematika menggunakan model Realistic Mathematics Education siswa kelas IV SDN 44 Bengkulu Tengah.

\section{Metode}

Jenis penelitian yang digunakan adalah penelitian tindakan kelas (classroom action research). Menurut Wardani (2007) penelitian tindakan kelas adalah penelitian yang dilakukan guru di dalam kelas melalui refleksi diri dengan tujuan untuk memperbaiki kinerja guru sehingga hasil belajar siswa meningkat. Penelitian tindakan kelas ini dilakukan sebanyak dua siklus. Setiap sikklus terdiri dari tahap perencanaan, tindakan, pengamatan dan refleksi. Penelitian tindakan kelas ini untuk membantu memecahkan masalah dan memperbaiki proses pembelajaran matematika secara reflekstif dan kolaboratif. Subyek penelitian ini adalah siswa kelas IV SDN 44 Bengkulu Tengahyang berjumlah 16 orang, terdiri 11 perempuan dan 5 laki-laki.

Teknik pengumpulan data dalam penelitian ini menggunakan metode sebagai berikut: 1) observasi bertujuan untuk mengumpulkan data dengan seksama dan sistematis, 2) dokumentasi berbentuk catatan tertulis tentang berbagai kegiatan atau peristiwa pada masa yang lalu, 3) tes dijadikan sebagai nilai ukur tingkat penguasaan materi (Gulo, 2002). Instrumen yang digunakan dalam penelitian ini adalah lembar observasi aktivitas guru dan aktivitas siswa serta lembar tes. Lembar observasi aktivitas guru dan siswa digunakan untuk melihat aktivitas selama proses pembelajaran. Sedangkan lembar tes digunakan untuk mengukur keberhasilan siswa dalam menguasai konsep atau hasil belajar. Analisis data menggunakan teknik kualitatif dan kuantitatif. Teknik kualitatif digunakan untuk menganalisis lembarobservasi saat proses pembelajaran. Skala penilaian dikelompokan kedalam 4 kategori, yaitu: sangat baik, baik, cukup dan kurang dengan skor 4, 3, 2, 1 (Sudjana, 2016).

Teknik kuantitatif digunakan untuk menganalisis tingkat keberhasilan hasil belajar dengan menggunakan rumus sebagai berikut.

Data rata-rata hasil belajar siswa

$\bar{x}=\frac{\sum X}{N}$

Keterangan:

$\bar{x}=$ Rata-rata hitung

$\sum \mathrm{x}=$ Jumlah Nilai

$\mathrm{N}$ = Jumlah Siswa

Data ketuntasan belajar siswa

$\mathrm{KB}=\frac{N S}{N} \mathrm{X} 100 \%$

Keterangan:

$\mathrm{KB}=$ Ketuntasan Belajar 
NS = Jumlah Siswa yang mendapat nilai $\geq 70$

$\mathrm{N}=$ Jumlah Siswa

Sudjana (2016)

\section{Hasil}

\section{Hasil Penelitian Siklus I}

Pembelajaran siklus I membahas tentang konsep pecahan senilai menggunakan benda konkrit dan gambar. Langkah-langkah penelitian dilakukan sebagai berikut.

a. Tahap perencanaan

Dalam perencanaan siklus I meliputi: 1) menyusun RPP menggunakan model RME, 2) meyiapkan alat peraga berupa benda konkrit, seperti pizza, kue bolu,donat dan PPT tentang gambar pizza, bolu, donat, 3) menyusun Lembar Kerja Peserta Didik (LKPD), 4) menyiapkan lembar observasi aktivitas guru dan siswa dan 5) menyiapkan soal evaluasi.

b. Pelaksanaan tindakan

Guru mengajarkan konsep pecahan senilaidengan langkah-langkah sebagai berikut.

1) Memahami masalah kontekstual, pada tahap ini guru memberikan permasalahan tentang pecahan senilai dengan cara memotivasi siswa untuk video seorang Ibu yang memotong kue bolu pertama menjadi empat bagian dan kue bolu kedua menjadi delapan bagian sama besar.Selanjutnya guru melakukan tanya jawab, seperti: a) berapakah nilai pecahan pada potongan kue bolu pertama, b) nilai pecahan kue bolu kedua, c) jika kue bolu pertama diambil satu potong dan kue bolu kedua diambil dua potong apa besarnya sama,

2) menyelesaikan masalah kontektual, pada tahap ini siswa dibentuk menjadi empat kelompok. Setiap kelompok diberi tugas mengerjakan LKPD untuk menemukan konsep pecahan senilai dengan menggunakan benda konkrit dan kemudian digambarkan,

3) membandingkan dan mendiskusikan jawaban, pada tahap ini setiap kelompok diminta melaporkan hasil diskusi dan membandingkan hasil diskusi dari masing masing kelompok dan

4) menarik kesimpulan, pada tahap ini siswa dibimbing menyimpulkan hasil diskusi tentang pecahan senilai, mulai dari konsep yang ditemukan, prosedur yang digunakan sampai ke rumus untuk menentukan pecahan senilai.

c. Tahap observasi

Observasi ini untuk melihat proses pembelajaran yang dilakukan guru di kelas. Sebagai observer yaitu teman sejawat dan kepala sekolah dengan menggunakan lembar observasi aktivitas guru dan siswa. Selama proses pempelajaran observer mencatat aktivitas guru meliputi: 1) membimbing siswa memahami permasalahan, 2) memfasilitasi siswa melakukan Tanya jawab, 3) membimbing siswa berdiskusi mengerjakan LKPD, 4) Membimbing siswa melaporkan hasil diskusi dan 5) membimbing siswa menarik kesimpulan. Hasil pengolahan data aktivitas guru disajikan pada tabel berikut.

Tabel 1. Hasil Observasi Aktivitas Guru Siklus I

\begin{tabular}{cccc}
\hline Materi & Observer & Skor & Kriteria \\
\hline Konsep pecahan senilai & I & 3,0 & Baik \\
\cline { 2 - 4 } & II & 3,4 & Baik \\
\hline Rata -rata & & 3,2 & Baik \\
\hline
\end{tabular}

Selanjutnya aktivitas siswa meliputi: 1) memahami masalah melalui tayangan video, 2) melakukan tanya jawab, 3) melakukan diskusi mengerjakan LKPD, 4) melaporkan hasil diskusi dan 5) Membuat kesimpulan. 
Adapun hasil aktivitas siswa disajikan pada tabel berikut.

Tabel 2. Hasil Observasi Aktivitas Siswa Siklus I

\begin{tabular}{cccc}
\hline Materi & Observer & Skor & Kriteria \\
\hline Konsep pecahan senilai & I & 3,2 & Baik \\
\cline { 2 - 4 } & II & 3,4 & Baik \\
\hline Rata -rata & & 3,3 & Baik \\
\hline
\end{tabular}

Di akhir pembelajaran siswa diberikan soal tes untuk mengetahui tingkat keberhasilan proses pembelajaran siklus I. Hasil analisis pengolahan data hasil belajar siswa siklus I disajikan pada tabel berikut.

Tabel 3. Hasil Belajar Siswa Siklus I

\begin{tabular}{|c|c|}
\hline Uraian & Hasil \\
\hline Jumlah siswa yang ikut tes & 16 \\
\hline Skor Terendah & 50 \\
\hline Skor Tertinggi & 90 \\
\hline Jumlah skor & 1100 \\
\hline Rata-rata skor & 68,75 \\
\hline Jumlah siswa yang tuntas & 9 \\
\hline Jumlah siswa yang tidak tuntas & 7 \\
\hline Persentase ketuntasan & $62,50 \%$ \\
\hline Keterangan & Belum tuntas \\
\hline
\end{tabular}

d. Refleksi

Pada tahap refleksi ini Kepala Sekolah, teman sejawat dan peneliti melakukan diskusi untuk mengetahui kelebihan dan kekurangan selama proses pembelajaran. Dari hasil diskusi ditemukan kelebihan pembelajaran siklus I, yaitu : 1) guru sudah membimbing siswa melakukan Tanya jawab dengan baik, 2) guru membimbing siswa melaporkan hasil diskusi dengan baik, 3)siswa sudah melaporkan hasil diskusi dengan runtus dan sistimatis. Adapun kelemahan, sebagai berikut: 1) guru belum memberikan bimbingan dalam memahami masalah secara maksimal, 2)ketika diskusi lebih didominasi siswa yang pintar dan siswa lain ribut,3) sebagian siswa masih pasip dan 4) Nilai rata-rata masih rendah yaitu 68,75 dengan ketuntasan belajar $62,50 \%$

\section{Hasil Penelitian siklus II}

a. Tahap perencanaan

Perencanaan yang dilakukan pada siklus ke II dilakukan dengan memperhatikan kelemahan siklus I .Adapan perencanaan yang dilakukan guru yaitu: 1) menyusun RPP menggunakan model RME dengan materi soal cerita atau pemecahan masalah yang berkaitan dengan pecahan senilai, 2) membuat Lembar Kerja Peserta Didik (LKPD), 3) menyiapkan lembar obsevasi aktivitas guru,4) menyiapkan lembar observasi siswa dan 5)menyiapkan tes evaluasi.

b. Tahap Tindakan

Guru mengajarkan soal cerita yang berkaitan dengan pecahan senilaidengan langkah -langkah sebagai berikut: 1) memahami masalah kontekstual, pada tahap ini guru memberikan permasalahan dalam kehidupan sehari-hari yang berkaitan dengan pecahan senilai. Siswa diminta mengamti gambar pedagang kue bolu yang menjual kue dengan potongan yang berbeda-beda dan harga yang berbeda juga. Selanjutnya guru melakukan tanya jawab dengan siswa bagaiman cara untuk mendapatkan potongan kue yang banyak dengan harga yang sama, 2) menyelesaikan masalah kontektual, pada tahap ini siswa dibentuk menjadi empat kelompok. Setiap kelompok diberi tugas mengerjakan LKPD tentang menyelesaikan soal cerita dengan prosedur yang benar, 3) membandingkan dan mendiskusikan jawaban, pada tahap ini setiap kelompok diminta melaporkan hasil diskusi dan membandingkan hasil diskusi dari masing masing kelompok dan 4) menarik 
kesimpulan, pada tahap ini siswa dibimbing menyimpulkan hasil diskusi tentang cara menyelesaikan soal cerita dengan prosedur yang benar

c. Tahap observasi

Pada tahap ini kepala sekolah dan teman sejawat mengamati aktivitas guru dan siswa selama proses pembelajaran. Hasil pengolahan data aktivitas guru Siklus II disajikan pada tabel berikut :

Tabel 4. Hasil Observasi Aktivitas Guru Siklus II

\begin{tabular}{cccc}
\hline Materi & Observer & Skor & Kriteria \\
\hline Soal cerita & I & 3,60 & Sangat Baik \\
\cline { 2 - 4 } & II & 3,80 & Sangat Baik \\
\hline Rata -rata & & 3,70 & Sangat Baik \\
\hline
\end{tabular}

Adapun hasil pengolahan data aktivitas siswa siklus II disajikan pada tabel berikut.

Tabel 5. Hasil Observasi Aktivitas Siswa Siklus II

\begin{tabular}{cccc}
\hline Materi & Observer & Skor & Kriteria \\
\hline Soal cerita & I & 3,60 & Sangat Baik \\
\cline { 2 - 4 } & II & 3,60 & Sangat Baik \\
\hline Rata -rata & & 3,60 & Sangat Baik \\
\hline
\end{tabular}

Di akhir pembelajaran siswa diberikan soal tes untuk mengetahui tingkat keberhasilan proses pembelajaran siklus II. Hasil analisis pengolahan data hasil belajar siswa siklus II disajikan pada tabel berikut.

Tabel 6. Hasil Belajar Siswa Siklus II

\begin{tabular}{lc}
\hline \multicolumn{1}{c}{ Uraian } & Hasil \\
\hline Jumlah siswa yang ikut tes & 16 \\
\hline Skor Terendah & 60 \\
\hline Skor Tertinggi & 90 \\
\hline Jumlah skor & 1200 \\
\hline Rata-rata skor & 80 \\
\hline Jumlah siswa yang tuntas & 14 \\
\hline Jumlah siswa yang tidak tuntas & 2 \\
\hline Persentase ketuntasan & $87,50 \%$ \\
\hline Keterangan & Tuntas \\
\hline
\end{tabular}

\section{d. Tahap Refleksi}

Peneliti, guru kelas dan kepala sekolah melakukan diskusi untuk menemukan kelebihan dan kekuranga. Kelebihan pada siklus II, yaitu 1) siswa sudah terlibat aktif memahami masalah,2)siswa antusian melakukan tanya jawab, 3)siswa sudah terlibat aktif berdiskusi untuk memecahkan masalah,4) siswa sudah berani menanggapi hasil diskusi kelompok lain dan 5) rata-rata nilai dan ketuntasan belajar sudah tercapai. Adapun kelemahannya masih 2siswa yang mendapat nilai kurang dari KKM dan perlu bimbingan secara khusus.

\section{Pembahasan}

\section{Aktivitas Pembelajaran}

\section{a. Siklus I}

Pembelajaran pada siklus I membahas materi konsep pecahan senilai.Proses pembelajaran yang dilakukan dengan langkah-langkah : 1) memahami masalah kontekstual,2) menyelesaikan masalah kontekstual, 3)membandingkan dan mendiskusikan jawaban, 4) menarik kesimpulan. 
Pada langkah memahami masalah kontekstual, guru menayangkan video seorang Ibu yang memotong dua kue bolu. Kue bolu pertama dipotong menjadi empat bagian dan kue bolu kedua dipotong menjadi empat bagian. Selanjutnya Ibu mengambil satu potong dari kue pertama dan dua potong dari kue kedua. Sesuai dengan pendapat Fathurrohman (2015) mengemukakan pendekatan pembelajaran RME menggunakan situasi dunia nyata atau konteks real dan pengalaman siswa dalam kehidupan sehari-hari sebagai titik tolak belajar. Selanjutnya guru melakukan tanya jawab dari tayangan video tersebut. Tanya jawab diarahkan siswa memahami nilai pecahan dari potongan kue pertama dan kue kedua sampai akhirnya siswa diarahkan bisa memahami besar satu potong kue pertama sama dengan dua potong kue kedua. Selama proses Tanya jawab siswa terlihat antusias, senang dan aktif mencari jawaban. Hal sesuai dengan pendapat Maulana dalam Isrok'atun (2018) yang menyatakan dalam pembelajaran matematika realistic menggunakan masalah kontekstual dan bersumber dari kehidupan nyata, siswa terlibat aktif dan mudah memahami permasalahan yang dibahas.

Pada langkah menyelesaikan masalah, siswa dibentuk menjadi empat kelompok. Setiap kelompok dibagikan LKPD dan alat peraga berupa kue bolu. Siswa diarahkan berdiskusi menyelesaikan soal atau masalah yang di LKPD untuk menemukan konsep pecahan senilai. Siswa saling kerjasama ketika mencoba memotong kue dengan berbagai potongan yang berbeda. Hasil dari potongan kue sangat bervariasi dan siswa lebih kreatif untuk menemukan pecahan senilai. Selama diskusi guru memberikan bimbingan pada kelompok, meskipun belumsecara maksimal untuk setiap kelompok, Sesuai pendapat Isrok'atun (2018) menyatakan dalam pembelajaran menggunakan model RME, siswa diberi kesempatan membangun suatu konep matematika melalui kegiatan yang dikembangkan secara mandiri. Sesuai dengan hasil penelitian Jarmita (2019), hasil penelitian menunjukkan bahwa persentase pemahaman konsep meningkat, pada siklus I hasil tes yaitu 69,06\% (Sedang), mengalami peningkatan pada siklus II yaitu 73,5\% (Sedang), begitupun selanjutnya mengalami peningkatan pada siklus III yaitu $81,04 \%$ (Tinggi) dan berhenti di siklus III dikarenakan telah mencapai kualifikasi pemahaman konsep yang tinggi dan telah mengalami peningkatan yang signifikan.

Pada langkah membandingkan dan mendiskusikan masalah, guru memberikan kesempatan kepada setiap kelompok untuk melaporkan hasil diskusi dan kelompok lain menanggapi. Pada awalnya siswa nampak ragu-ragu untuk melaporkan hasil diskusinya, sehingga guru memberikan motivasi lehih dahulu. Setelah dimotivasi siswa dengan semangat melaporkan hasil diskusinya dan kelompok lain menanggapi dengan mengajukan pertanyaan. Siswa mencoba untuk saling mengajukan pertanyaan pada kelompok yang tampil.

Pada langkah menarik kesimpulan, siswa diberi kesempatan untuk membuat kesimpulan. Guru mengarahkan siswa untuk menyimpulkan materi pelajaran yang dibahas mulai dari menemukan konsep pecahan senilai dengan menggunakan kue bolu, menggambarkan potongan kue dan nilai pecahan sampai siswa bisa menyimpulkan rumus mencari pecahan senilai. Sesuai pendapat Shoimin (2014) menyatakan bahwa model RME memberikan pemahaman kepada siswa dalam mempelajari matematika, proses pembelajaran merupakan suatu aktivitas utama yang dilakukan untuk menemukan konsep. Setelah proses pembelajaran berakhir, selanjutnya guru memberikan soal evaluasi untuk mengukur keberhasilan belajar.

Hasil observasi dari dua observer terhadap aktivitas guru dan aktivitas siswa selanjutnya dianalisis. Hasil analisis pengolahan data aktivitas guru dari dua observer yaitu 3,20 pada katagori baik dan aktivitas siswa 3,30 pada kriteria baik. 
Dari hasil refleksi, pada aktivitas guru perlu perbaikan dalam pembimbingan diskusi kelompok dan pembimbingan secara khusus bagi siswa yang belum menguasai materi, sedangkan pada aktivitas siswa masih perlu memberikan bimbingan dalam diskusi dan melibatkan seluruh siswa secara aktif. Sesuai hasil penelitian Istiana (2015) mengemukakan bahwa aktivitas belajar siswa merupakan hal yang penting dalam proses pembelajaran.

\section{b. Siklus II}

Pembelajaran pada siklus II membahas materi tentang pemecahan masalah dalam kehidupan sehari-hari yang berkaitan dengan pecahan senilai. Proses pembelajaran yang dilakukan dengan langkah-langkah 1) memahami masalah kontekstual,2) menyelesaikan masalah kontekstual, 3) membandingkan dan mendiskusikan jawaban, dan 4) menarik kesimpulan.

Pada langkah memahami masalah kontekstual, guru menayangkan video tentang pedagang kue bolu yang menjajakan kuenya dengan potongan yang berbeda dan dengan harga yang berbeda juga. Kue bolu pertama dipotong menjadi empat bagian dan setiap potong harganya Rp5.000,00 dan kue bolu kedua dipotong menjadi delapan bagian dengan harga setiap potong Rp2.500,00. Selanjutnya guru melakukan tanya jawab dari tayangan video tersebut. Tanya jawab diarahkan siswa memahami satu potong kue pertama dengan harga Rp5.000,00 dan dan dua potong kue kedua dengan harga sama. Selama proses Tanya jawab siswa terlihat semangat gembira, antusias dan aktif mengemukakan ide dan kontribusi. Sesuai dengan pendapat Maulana (Isrok'atun, 2018) mengemukakan bahwa dalam pembelajaran matematik realistic siswa berperan sebagai subyek belajar, siswa ditutut bisa memberikan kontribusi, ide dan gagasan untuk menemukan konsep.

Pada langkah menyelesaikan masalah, siswa dibentuk menjadi empat kelompok. Setiap kelompok dibagikan LKPD dan alat peraga berupa kue bolu. Siswa diarahkan berdiskusi menyelesaikan soal cerita dengan menggunakan prosedur yang benar. Didukung hasil penelitian Muharyanti (2019) menunjukkan bahwa ada peningkatan kemampuan menyelesaikan soal cerita Matematika pada siswa kelas IV B SD Negeri Bhayangkara. Peningkatan persentase yaitu pada siklus I dengan persentase $61 \%$ menjadi $82 \%$. Selain itu, terdapat pula peningkatan perolehan rata-rata nilai tes siklus I sebesar 71,1 dan ratarata nilai tes siklus II sebesar 80,2. Siswa terlihat kreatif dan aktif menggambar kue bolu dengan potongan yang berbeda dan memasang tarif harga yang berbeda juga. Selama diskusi siswa terlihat aktif dan kreatif dalam mengkaitan konsep dengan cara yang berbeda untuk memecahkan masalah. Dalam diskusi guru memberikan bimbingan secara maksimal untuk setiap kelompok, Sesuai hasil penelitian Karjiyati dkk (2014) menunjukkan bahwa pembelajaran matematika menggunakan model Quantum Teaching menggunakan RME dapat meningkatkan meningkatkan pemahaman konsep, kreativitas dan karakter siswa SD.

Pada langkah membandingkan dan mendiskusikan masalah, guru memberikan kesempatan kepada setiap kelompok untuk melaporkan hasil diskusi dan kelompok lain menanggapi. Ketika melaporkan hasil diskusi siswa mulai berani dan percaya diri dalam presentasi dan kelompok lain semangat dalam menanggapi. Dari hasil presentasi menunjukkan siswa sudah memahami konsep pecahan senilai untuk memecahkan soal cerita. Hal ini sesuai dengan hasil penelitian Azilah (2019) Penggunaan pendekatan RME dapat meningkatkan pemahaman konsep bangun datar pada siswa kelas IVB SDN Kotagede 3. Hal tersebut dapat dilihat dari persentase ketuntasan siklus I yaitu $73,44 \%$ dan siklus II yaitu $78,13 \%$ dengan indikator keberhasilan yaitu minimal $75 \%$. 
Pada langkah menarik kesimpulan, siswa diberi kesempatan untuk membuat kesimpulan. Guru mengarahkan siswa untuk menyimpulkan materi pelajaran yang dibahas mulai dari menggambar kue yang dipotong dengan potongan yang berbeda dan dengan harga yang berbeda, namun menunjukkan bahwa sebenarnya nilainya sama. Siswa juga menyampaikan prosedur menyelesaikan pemecahan masalah atau soal cerita.Sesuai pendapat Mushsetyo (2013), mengemukan bahwa siswa mampu menyelesaikan soal cerita jika memahami susunan atau makna kalimat dengan benar, mengubah soal cerita menjadi kalimat matematika, memilih algoritma atau prosedur yang sesuai dan menggunakan algoritma atau prosedur yang benar.

Hasil analisis pengolahan data aktivitas guru dari dua observer yaitu 3,70 pada katagori sangat baik dan aktivitas siswa 3,60 pada kreteria sangat baik. Dari hasil refleksi, pada aktivitas guru perlu perbaikan dalam pembimbingan secara khusus bagi siswa yang belum menguasai materi, sedangkan pada aktivitas siswa masih perlu memberikan bimbingan dalam diskusi dan melibatkan seluruh siswa secara aktif.

\section{Hasil belajar \\ a. Siklus I}

Dari hasil belajar diperoleh rata-rata 68,75 dengan ketuntasan belajar 62,50\% dan masih ada 7 siswa yang belum tuntas. Model pembelajaran RME menekankan dalam proses pembelajaran matematika menggunakan konteks atau permasalahan nyata yang berupa masalah dalam kehidupan sehari-hari untuk menemukan penemuan konsep sehingga pembelajaran menjadi bermakna (Wijaya, 2012).Sesuai pendapat Bruner dalam Winarni (2012) menyatakan bahwa proses belajar akan berjalan dengan baik jika guru memberikan kesempatan kepada siswa untuk lebih kreatif dalam menemukan suatu konsep, teori, aturan, atau pemahaman melalui contoh-contoh yang dijumpai dalam kehidupan sehari-hari.

\section{b. Siklus II}

Dari hasil belajar diperoleh rata-rata 80,00 dengan ketuntasan belajar 87,50\% dan masih ada 2 siswa yang belum tuntas. Sesuai pendapat Bruner dalam Winarni (2012) menyatakan bahwa proses belajar akan berjalan dengan baik jika guru memberikan kesempatan kepada siswa untuk lebih kreatif dalam menemukan suatu konsep, teori, aturan, atau pemahaman melalui contoh-contoh yang dijumpai dalam kehidupan sehari-hari.

Penelitian Tindakan Kelas ini dilakukan sebanyak dua siklus, hasil penelitian pada siklus II sudah mencapai indikator keberhasilan. Hasil penelitian menunjukkan bahwa aktivitas guru pada siklus I diperoleh rata-rata3,20 meningkat pada siklus II diperoleh rata-rata 3,70. Hasil aktivitas siswa pada siklus I diperoleh rata-rat 3,30 meningkat pada siklus II menjadi 3,60. Hasil belajar siswa pada siklus I diperoleh rata-rata 68,75 dan ketuntasan belajar 62,50 meningkat pada siklus II dengan perolehan rata-rata 80,0 dan ketuntasan belajar 87,50\%. Hal ini sesuai dengan hasil penelitian Kurnia berdasarkan hasil analisis data dapat disimpulkan bahwa penerapan model RME dapat meningkatkan hasil belajar dalam proses pembelajaran matematika siswa kelas IV SDN Karangmangu dari siklus I sebesar $65 \%$ dengan kategori sangat baik (SB) menjadi $87 \%$ pada siklus II dengan kategori sangat baik (SB).

\section{Simpulan}

Berdasarkan hasil penelitian dapat disimpulkan, sebagai berikut: 1) Penerapan model RME dapat meningkatkan aktivitas guru, yang dibuktikan perolehan nilai rata- rata skor siklus I, yaitu 3,20 berada pada kategori baik, meningkat pada siklus II menjadi 3,70 pada kategori sngat baik, 2) Penerapan model RME dapat meningkatkan aktivitas siswa yang dibuktikan dengan perolehan rata-rata aktivitas 
siswa siklus I, yaitu 3,30 pada katagori baik, meningkat pada siklus II menjadi 3,60 pada katagori sangat baik, 3) Penerapan model RME dapat meningkatkan hasil belajar matematika, pada siklus I diperoleh rat-rata 68,75 dengan ketuntasan belajar $62,50 \%$ meningkat padsa siklus II menjadi 80,00 dengan ketuntasan belajar $87,50 \%$.

Berdasarkan simpulan di atas, saran dalam penelitian ini adalah sebagai berikut: 1) sebaiknya dalam pembelajaran matematika guru dapat menerapkan model RME karena pembelajaran lebih inovatif, menarik, menyenangkan dan bermakna, 2) dalam menerapkan model RME sebaiknya guru menggunakan masalah kontekstual dan bersumber dari peristiwa nyata dalam kehidupan sehari-hari.

\section{Referensi}

Azilah, R., N. (2019). Penggunaan Pendekatan Realistic Mathematics Education (Rme) Dalam Peningkatan Pemahaman Konsep Bangun Datar Siswa Kelas IV SD. Jurnal PTK Pendidikan Profesi Guru Prajabatan 2018.

Depdiknas. (2006). Pedoman Penyusunan Kurikulum Tingkat Satuan Pendidikan di Sekolah Dasar. Jakarta: Badan Standar Nasional Pendidikan

Fathurrohman. M. (2015). Model-model Pembelajaran Inovatif. Yogyakarta: Ar-Ruzz Media

Gulo, W. (2002). Metodologi Penelitian. Jakarta: PT Gramedia Widiasarana Indonesia

Hadi, S. (2017). Pendidikan Matematika Realistik: Teori, Pengembangan dan Implementasinya. Jakarta: Rajawali Pers.

Hawa, S. (2008). Pengembangan Pembelajaran Matematika SD. Jakarta: Dirjen Dikti Depdiknas

Heruman. (2007). Model Pembelajaran Matematika di Sekolah Dasar. Bandung: PT Remaja Rosdakarya.

Isrok'atun dan Rosmala. (2018). Model-model Pembelajaran Matematika. Jakarta: PT Bumi Aksara.

Jarmita, N. (2019). Penerapan Pendekatan Realistic Mathematics Education untuk Meningkatkan Pemahaman Konsep Matematika Siswa SD. Jurnal Keilmuan dan Kependidikan Dasar UIN Banten, 11(2).

Karjiyati, V., Winarni, E., W., \& Noperman, F. (2014). Pengembangan Model Quantum Teaching dalam Pembelajaran Matematika Menggunakan Realistic Matematic Education Untuk Meningkatakan Prestasi belajar, Kreativitas dan Karakter siswa SD. Prosiding Seminar Nasional PGSD FKIP UNIB.

Kurnia. I. (2019). Penerapan Pendekatan Realistic Mathematics Education (RME) Untuk Meningkatkan Hasil Belajar Matematika Siswa Kelas IV SDN 1 Karangmangu. Jurnal Penelitian Pendidikan PGSD FKIP UNIKU, 6(1).

Wheny, T., M. (2019). Peningkatan Kemampuan Menyelesaikan Soalcerita Matematika Melalui Model Pembelajaran Problem Based Learning Pada Siswa Kelas IV SDN. Jurnal PTK Pendidikan Profesi Guru Prajabatan 2018.

Musetyo. G. (2007). Pembelajaran Matematika SD. Jakarta: Universitas Terbuka.

Purwanto. (2010). Evaluasi Hasil Belajar. Yogyakarta: Pustaka Pelajar

Shandy, M. (2016). Realistic Mathematics Education untuk Meningkatkan Hasil Belajar Siswa Sekolah Dasar. Jurnal Pendidikan Guru Sekolah Dasar UPI, $1(1)$

Shoimin, A. (2014). 68 Model Pembelajara Inovatif dalam Kurikulum 2013. Yogyakarta: AR-RUZZ MEDIA

Sudjana, N. (2016). Penilaian Proses Hasil Belajar Mengajar. Bandung: PT Remaja Rosdakarya

Susilowati, E., (2018). Peningkatan Aktivitas dan Hasil Belajar Matematika Siswa SD Melalui Model Realistic Mathematics Education (RME) Pada Siswa Kelas 
IV Semester I di SD Negeri 4 Kradenan Kecamatan Kradenan kabupaten Grobogan Tahun pelajaran 2017/2018. Jurnal PINUS, 4(1)

Trianto. (2009). Mendesaian Model Pembelajaran Inovatif-Progresif: Konsep, Landasan, dan Implementasinya Pada Kurikulum Tingkat Satuan Pendidikan. Jakarta: Kencana 2010.

Wardhani. I. (2007). Penelitian Tindakan Kelas. Jakarta: Universitas Terbuka

Wijaya, A. (2012). Pendidikan Matematika Realistic suatu Alternatif Pendekatan Pembelajaran Matematika. Yogyakarta: Graha Ilmu

Winarni, E., S. (2011). Matematika Untuk PGSD. Bandung: PT Remaja Rosdakarya 